\title{
Seroprevalence of toxocariasis in children aged 1-9 years in western Islamic Republic of Iran, 2003
}

\author{
M. Fallah, ${ }^{1}$ A. Azimi ${ }^{2}$ and H. Taherkhani ${ }^{3}$
}

$$
\begin{aligned}
& \text { معدل الانتثار المصلي لداء السهميات بين الأطفال من عمر } 1 \text { إلى } 9 \text { سنوات في غرب جمهرريـة إيـران } \\
& \text { الإسلامية سنة } 2003
\end{aligned}
$$

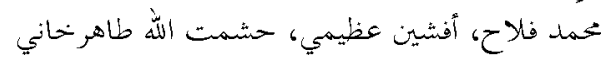

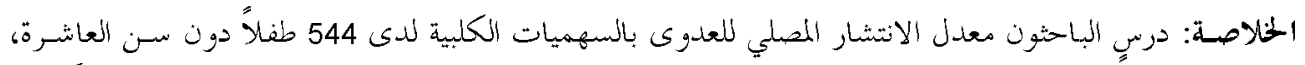

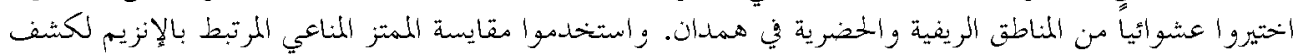

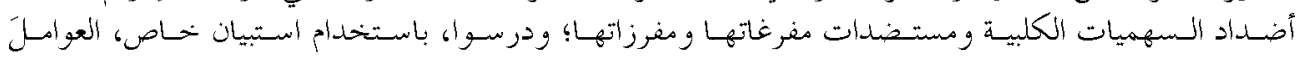

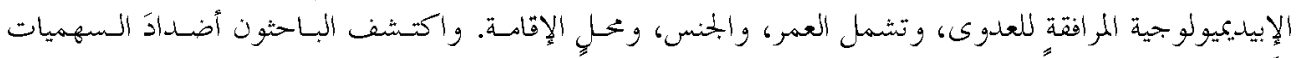

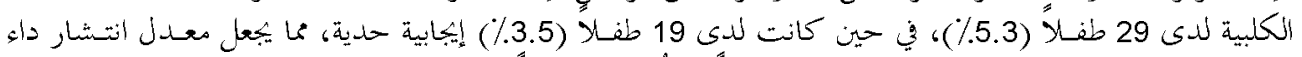

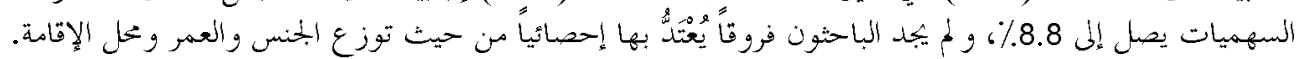

ASTRACT We determined the seroprevalence of Toxocara canis infection in 544 children under 10 years randomly selected from urban and rural areas of Hamadan. An enzyme-linked immunosorbent assay was used for detection of antibodies to $T$. canis excretion-secretion antigens. Using a questionnaire, epidemiological factors associated with infection were examined, including age, sex, residence. Antibodies to T. canis were detected in 29 children (5.3\%) and 19 children (3.5\%) were categorized as borderline positive; thus together this gave a prevalence of toxocariasis of $8.8 \%$. No significant differences were found in terms of sex, age and residence.

Séroprévalence de la toxocariose chez l'enfant de 1 à 9 ans dans la région occidentale de la République islamique d'Iran en 2003

RÉSUMÉ Nous avons déterminé la séroprévalence de l'infection à Toxocara canis chez 544 enfants de moins de 10 ans résidant dans les zones rurales et urbaines d'Hamadan et sélectionnés au hasard. La détection des anticorps contre les antigènes excrétoires-sécrétoires de $T$. canis a été effectuée à l'aide d'un test immunoenzymatique (ELISA, pour enzyme-linked immunosorbent assay). Un questionnaire a permis l'évaluation des facteurs épidémiologiques associés à l'infection, notamment l'âge, le sexe et le lieu de résidence. Des anticorps anti- $T$. canis ont été détectés chez 29 enfants $(5,3 \%)$, tandis qu'une positivité limite a été enregistrée chez 19 autres (3,5\%), établissant ainsi une prévalence de la toxocariose à $8,8 \%$. Aucune différence significative n'est apparue liée à l'âge, au sexe ou au lieu de résidence.

${ }^{1}$ Department of Parasitology and Mycology, School of Medicine, Hamadan University of Medical Sciences, Hamadan, Islamic Republic of Iran (Correspondence to M. Fallah: mohfall@yahoo.com).

${ }^{2}$ Atieh Hospital, Hamadan, Islamic Republic of Iran.

${ }^{3}$ Gorgan University of Medical Sciences, Gorgan, Islamic Republic of Iran.

Received: 18/05/05; accepted: 07/07/05 


\section{Introduction}

Toxocara canis is one of the commonest nematodes of the dog and most often this nematode is the cause of toxocariasis (visceral larva migrans) [1]. People become infected by ingestion of eggs from soil, dirty hands (thumb-sucking) and raw vegetables. Pica has an important role in the acquisition of this infection. Once embryonated eggs are ingested, the larvae hatch and migrate through the somatic organs [2].

In humans, migration of $T$. canis larvae to viscera and other organs produces visceral larva migrans syndrome, and sometimes ocular larva migrans and neurotoxocariasis [3].

Toxocariasis is considered to be a disease mainly of children, although adults can also be affected. Children are more at risk of acquiring this infection because of their attraction to pets (dogs and cats) and their play habits, which may expose them to accidental ingestion of Toxocara eggs from the animal hosts.

Direct confirmation of larva in internal organs is extremely difficult. Emphasis is placed on diagnosing visceral larva migrans and ocular larva migrans by indirect serological methods [4]. Diagnosis of human toxocariasis through most immunological tests is done using $T$. canis excretionsecretion antigens, most often by enzymelinked immunosorbent assay (ELISA) $[5,6]$.

There have been few epidemiological studies on the prevalence of toxocariasis in the Islamic Republic of Iran, especially in western parts such as Hamadan, except some sporadic reports of disease in children [7]. In this province human ascariasis is endemic and canine ascarids are common as well [8]. In central Hamadan, Ascaris lumbricoides prevalence is reported to be $20 \%$, and the prevalence of canine ascarids is reported to be about $51 \%$ in stray dogs [9] and there are thousands of stray dogs in and around the city without any control measures. Soil-contamination by Toxocara eggs in public parks has been reported previously $[10,11]$ and clinical evidence suggests the presence of human toxocariasis in this region. Environmental and sociocultural conditions facilitate infection with Toxocara eggs in humans, especially children. As there is a lack of documented reports on the seroepidemiology of toxocariasis in our area, we aimed to assess the prevalence of the infection in children under 10 years of age and its association with certain factors.

\section{Methods}

The study was carried out from July to September 2003 in Hamadan. The total population of Hamadan is about 600000 , and the target population (under 10 years old) was about 101000 [12]. A total of 544 children aged 1-9 years (278 girls and 276 boys) were randomly selected from urban $(408,75 \%)$ and rural $(136,25 \%)$ areas of Hamadan. The children were selected from areas covered by 10 health centres in the city and 9 health centres in the rural areas. All members of households in the catchment areas of the health centres have a health file and code and this was the sampling frame from which the children were selected. Sample size was calculated proportionally according to residence with a probable prevalence of $15 \%$ in urban areas and $3 \%$ in rural areas with $95 \%$ confidence interval.

Data were collected using a questionnaire which included epidemiological factors such as age, sex, residence, parents' educational status, a history of close contact with dogs and/or cats, keeping pets in the home, exposure to soil, pica, eating raw 
vegetables, mode of vegetable washing, thumb-sucking and frequency of visits to outdoor parks. The questionnaires were completed by the parents and health staff.

Venous blood samples $(3 \mathrm{~mL})$ were collected from each child for detection and titration of antibodies to T. canis. Serum was separated on the same day as collection at the centre and then frozen at $-20^{\circ} \mathrm{C}$ until analysis. Informed consent was obtained from the parents for their child to participate.

The ELISA/IgG diagnostic kit was supplied by Test-Line Ltd Clinical Diagnostics, Czech Republic. The manufacturer claims a high specificity of $99.2 \%$ and sensitivity of $100 \%$. The ELISA procedure was carried out according to the manufacturer's instructions. An automated washer (Asys Sera Washer, Austria) and automated reader (Rosys Authos, Spain) were also used. The base serum dilution in this method was $1 / 200$. The intensity of colour of each well was read at $450 \mathrm{~nm}$ against the blank. Results were considered valid if the absorbance of the blank was less than 0.150 , of the positive control was $\geq 0.900$ and of the negative control was $\leq 0.200$, and the mean absorbance of cut-off was between 0.250 and 0.600 . For evaluation of the results, index positivity was used (absorbance of each tested sample divided by the mean absorbance of the cut-off that was obtained in the same test); the cut-off was calculated and appointed to 0.3 . According to the manufacturer recommendations, an index positivity $>1.1$ was considered positive, 0.9 to 1.1 as borderline and $<0.8$ as negative for $T$. canis infection.

\section{Statistical analysis}

Data were analysed by SPSS, version 10 and the chi-squared test was used to assess statistical differences. $P<0.05$ was considered significant.

\section{Results}

Of the 544 samples analysed, 29 were positive for Toxocara antibodies giving an overall prevalence of $5.3 \%$, obtained at a cut-off titre of $1 / 200$. In addition, $19(3.5 \%)$ of the samples had a borderline titre. Thus including the borderline cases as positive, we have a prevalence of toxocariasis of $8.8 \%$. Of the 29 children positive for toxocariasis, 24 had a low titre, 4 a medium titre and only 1 had a high titre (Table 1). Table 1 also shows the prevalence of antibodies to Toxocara according to age, sex and residence; other variables examined were either not significant or incomplete and were excluded and are not shown. There was no significant difference in the seropositivity according to sex $(5.3 \%$ males, $5.63 \%$ females, $P=$ $0.54)$ or age group (1-3 years $5.66 \%, 4-6$ years $5.3 \%$ and $7-9$ years $5.28 \%, P=0.97$ ). Although a lower prevalence was found in the urban areas $(5.63 \%)$ compared with the rural areas $(4.41 \%)$, this was not statistically significant $(P=0.69)$.

\section{Discussion}

We found the prevalence of confirmed toxocariasis to be $5.3 \%$; with the borderline cases included, this rose to $8.8 \%$. We expected a higher prevalence rate in this region because of the environmental and cultural conditions. Because the prevalence of infection varies in difference geographical regions, it may be that the positivity index recommended by the manufacturers is not appropriate for developing countries such as ours and the assessment of antibodies should, as much as is practical, take account of special regional conditions.

Seropositive rates for $T$. canis have been reported to be $2.8 \%$ in the general population and $4.6 \%-7.3 \%$ in children $1-11$ years old in the United States [11], 10.9\% in Jor- 


\begin{tabular}{|c|c|c|c|c|c|c|c|}
\hline Variable & $\begin{array}{c}\text { No. of } \\
\text { samples } \\
\text { analysed }\end{array}$ & $\begin{array}{l}\text { Samples } \\
\text { positive } \\
\text { No. }(\%)\end{array}$ & $\begin{array}{c}\text { Samples } \\
\text { negative } \\
\text { No. (\%) }\end{array}$ & $\begin{array}{c}\text { Samples } \\
\text { borderline } \\
\text { No. (\%) }\end{array}$ & $\begin{array}{l}\text { Odds } \\
\text { ratio }\end{array}$ & $\begin{array}{c}95 \% \\
\text { confidence } \\
\text { interval }\end{array}$ & $P$-value \\
\hline Age (years) & & & & & 0.87 & $0.62-1.38$ & 0.97 \\
\hline $1-3$ & 53 & $3(5.7)$ & $49(92.5)$ & $1(1.9)$ & & & \\
\hline $4-6$ & 264 & $14(5.3)$ & $240(90.9)$ & $10(3.8)$ & & & \\
\hline $7-9$ & 227 & $12(5.3)$ & 207 (91.2) & $8(3.5)$ & & & \\
\hline Sex & & & & & 0.92 & $0.64-1.2$ & 0.54 \\
\hline Male & 278 & $14(5.0)$ & $252(90.6)$ & $12(4.3)$ & & & \\
\hline Female & 266 & $15(5.6)$ & $244(91.7)$ & $7(2.6)$ & & & \\
\hline Residence & & & & & 0.84 & $0.58-1.34$ & 0.69 \\
\hline Rural & 136 & $6(4.4)$ & $124(91.2)$ & $6(4.4)$ & & & \\
\hline Urban & 408 & $23(5.6)$ & $372(91.2)$ & $13(3.2)$ & & & \\
\hline
\end{tabular}

dan [13], 25.6\% (132/519) in Shiraz, eastern Islamic Republic of Iran [8] and 3.1\% $(70 / 2129)$ in Ireland [14]. Other studies report seropositivity rates of $3.1 \%(16 / 314)$ in Korea [15], $17.7 \%$ and $2.1 \%$ in rural and urban children respectively in China [16], $62.3 \%$ in schoolchildren in Trinidad [17], and $3.6 \%$ and $17.2 \%$ in 2 different areas of Spain (Madrid and Tenerife) [18].

While we expected a higher seropositivity rate among this group of children, nonetheless the rate of $8.8 \%$ was considerably higher than that expected for the general population $(2.0 \%$ to $2.5 \%)$. The absence of a significant difference in the rate of positivity between families who owned a dog and those that did not suggests that infection was being acquired from communal sources such as parks and playgrounds. Soil contamination of public parks and playgrounds in Hamadan has been reported previously [10]. Furthermore, keeping dogs is not popular in either urban or rural areas because of Islamic beliefs about dogs. Therefore, the contamination of the environment with $T$. canis eggs from stray dogs is probably the common source of infestation of children. The potential transmission of infection in children is undoubtedly greater than adults because children often play in the contaminated environments. The considerable proportion of children who had been infected indicates the need for control of the canine pollution in the area.

In conclusion, the prevalence of toxocariasis among children in western parts of the Islamic Republic of Iran is the same as some other developing countries but lower than southern parts of the country. Nevertheless, it is relatively high, as is the prevalence of canine ascarids in this area and soil contamination of public parks with eggs. Therefore, toxocariasis does constitute a health problem in this area that needs to be addressed.

\section{Acknowledgements}

We thank the Deputy of Education, Hamadan University of Medical Sciences, who funded the study. We also thank the personnel of all the urban and rural health centres of Hamadan for their help in the collection of samples. 


\section{References}

1. Liu XL. Toxocariasis and larva migrans syndromes. In: Guerrant RL, Walker DH, Weller PF, eds. Tropical infectious diseases, vol. 2. Philadelphia, Churchill Livingstone, 1999:907-15

2. Schantz PM. Toxocara larva migrans now. American journal of tropical medicine and hygiene, 1989, 41(3 suppl.):21-34.

3. Gillespie SH et al. The spectrum of ocular toxocariasis. Eye, 1993, 7:415-8.

4. Sommer $\mathrm{C}$ et al. Adult Toxocara canis encephalitis. Journal of neurology, neurosurgery, and psychiatry, 1994, 57:229-31.

5. Jaquier $\mathrm{P}$ et al. Immunodiagnosis of toxocariasis in human: evaluation of a new enzyme-linked immunosorbent assay kit. Journal of clinical microbiology, 1991, 29(9):1831-5.

6. Yamasaki $\mathrm{H}$ et al. Development of a highly specific recombinant Toxocara canis second-stage larva excretory-secretory antigen for immunodiagnosis of human toxocariasis. Journal of clinical microbiology, 2000, 38(4):1409-13.

7. Sadjjadi SM et al. Seroprevalence of Toxocara infection in school children in Shiraz, southern Iran. Journal of tropical pediatrics, 2000, 46:327-30.

8. Fallah M. [Toxocara canis: infection of stray dogs and visceral larva migrans risk in Hamadan]. Scientific journal of Hamadan University of Medical Sciences, 1995, 2(2):18-22 [in Farsi].

9. Fallah $\mathrm{M}$ et al. Evaluation of two years mass chemotherapy against ascariasis in Hamadan, Islamic Republic of Iran. Bulletin of the World Health Organization, 2002, 80(5):399-402.

10. Fallah M, Majzoubi MM. Soil contamination of Hamadan public parks with ova of parasites and cyst and oocysts of protozoa. Paper presented at the 3rd Iranian Congress for Environmental Health, Kerman, Islamic Republic of Iran, 2000.

11. Herrmann $N$ et al. Seroprevalence of zoonotic toxocariasis in the United States: 1971-1973. American journal of epidemiology, 1985, 122:890-6.

12. Statistics Center of the Islamic Republic of Iran. [A monograph of Iranian National Census in 1996]. The Hamadan, Management and Planning Organization, 1997 [in Farsi].

13. Abo-Shehada MN et al. Seroprevalence of Toxocara canis antibodies in humans in northern Jordan. Journal of helminthology, 1992, 66:75-8.

14. Holland CV et al. Seroepidemiology of toxocariasis in school children. Parasitology, 1995, 110:535-45.

15. Park HY et al. A seroepidemiological survey for toxocariasis in apparently healthy residents in Gangwon-do, Korea. Korean journal of parasitology, 2002, 40(3):113-7.

16. Zhong-jin Luo et al. Detection of circulating antigens and antibodies in Toxocara canis infection among children in Chengdu, China. Journal of parasitology, 85(2), 1999:252-6.

17. Baboolal S, Rawlins SC. Seroprevalence of toxocariasis in children in Trinidad. Transactions of the Royal Society of Tropical Medicine and Hygiene, 2002, 96:139-43.

18. Fenoy S, Cuellar C, Guillen JL. Seroprevalence of toxocariasis in children and adults in Madrid and Tenerife, Spain. Journal of helminthology, 1996, 70:10913. 